\title{
Degradation processes and the methods of securing wall crests
}

\author{
Maciej Trochonowicz, Bogusław Szmygin
}

\author{
Monument Conservation Department, Architecture and Civil Engineering Faculty, \\ Lublin University of Technology,e-mails: b.szmygin@pollub.pl,m.trochonowicz@pollub.pl
}

\begin{abstract}
The protection of historical ruins requires solution of doctrinal and technical problems. Technical problems concern above all preservation of walls, which are exposed to the influence of atmospheric factors. The problem that needs to be solved in any historic ruin is securing of wall crests. Form of protection of the wall crests depends on many factors, mainly technical features of the wall and architectural and conservatory vision. The following article presents three aspects important for protection of wall crests. Firstly, analysis of features of the wall as a structure, secondly the characteristics of destructive agents, thirdly forms of protection of wall crests. In the summary of the following article, advantages and disadvantages of each method of preservation of the wall crests were presented.
\end{abstract}

Keywords: historical ruin, wall crests degradation, securing of wall crests.

\section{Introduction}

A characteristic feature of objects in the state of the so-called permanent ruin is a great number of detached walls. They comprise both the historically detached walls and the walls of the primarily cubature (or: volumetric) objects. The constructions, devoid of protective elements, are specially exposed to the danger of degrading factors activity. Due to that fact, the destructive processes are clearly faster here and the negative effects have a wider range than in the case of other objects. Certainly the biggest destruction has been observed at the wall crests, i.e. the part covering the lower parts of the walls, that is why it is so important to secure them properly.

\section{Characteristic features of ruined wall crests}

The state of the objects preserved as the so-called permanent ruin is a resultant of many processes taking place in those objects during the course of years. The most important ones are: materials and constructions of which they were erected, the time from their construction and the moment when they went to ruin, the factors responsible for the process of degradation, and the damage brought about by the man.

Analyzing the castle objects in the state of permanent ruin one may introduce a full range of typologies determining the form in which the walls have been preserved up to our times. The current article suggests the division based on the dimensions (height and width) and the shapes of the crests surmounting the walls.

The wall height. It happens quite often, that there are high, medium and low walls within the confines of one object. The division is certainly purely conventional and refers to the primary height of the walls and their actual height is concerned with the grade of destruction. High walls are those that have been preserved practically in an unchanged state. Their historical line has been preserved and the destruction traces are really scarce. The width of the crests and their profile is largely authentic. The most frequently appearing 
walls are certainly the middle ones whose height and the shape of the crest has been changed radically as compared to the primary one. The walls of medium height are those, that have lost a significant part of their upper portions, the line of crenels, shooting platforms etc. is not clearly seen. Due to the original cross-section, growing broader towards the lower parts and reducing the height of the wall, their crests are significantly wider than it is in case of high walls. The activity of the atmospheric factors makes the profile of the crests highly irregular. Another group consists of low walls which have been preserved up to our times as relics. There are, in fact, only remains of walls, slightly protruding above the area, leveled with it or even lower.

Thickness of the wall. The second, rather legible criterion of the division of walls in ruin is their volume. We can differentiate thin and thick walls. The division results, first of all, from the primary function of the object. Thin walls are mostly the relics of the earlier volumetric objects and the fragments of inner walls that did not perform the historically defensive function. Thick walls are most often the outer walls of the castle, the curtain walls and the inner walls of the object that are the remains of defensive objects (towers, turrets etc.). In a prevailing part of objects, due to the degradation processes, there are no preserved up to the present moment thin walls of the form, and they are presently totally illegible or preserved only as relics.

The shape of the crest. Another category is the shape of the wall crest. We can differentiate walls of regular crests slightly deflected from the level. The leveled line of the crest may result from the natural processes (taking into account the homogenous building material and the same primary dimensions, the processes looked similar), or may be the result of the contemporary works carried out at the object. Another group consists of walls with crests of irregular heights. The predominant part of this group is the group of walls of the primarily volumetric objects. They were often endowed with numerous doors and windows. After the destruction of the upper part the wall is left with the characteristic protruding remains of the inter-window pillars. The irregularity of the crest lines may also be caused by the conscious activity of man or result from the damages that have taken place in the object.

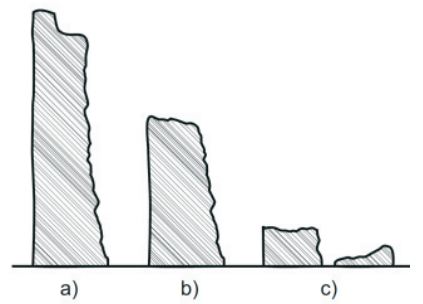

Fig. 1. The division of walls with respect to height: a) a high wall, b) a medium wall, c) a low wall

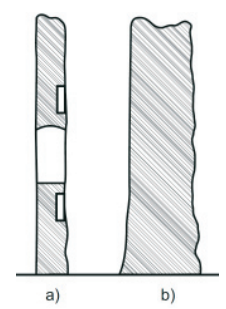

Fig. 2. The division of walls with respect to thickness:

a) a thin wall,

b) a thick wall
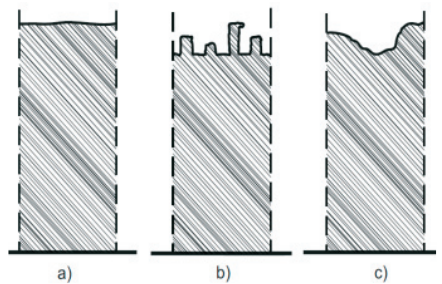

Fig. 3. The division of walls with respect to the crest shape: a) a wall with a leveled crest, b) a wall of a volumetric object window openings,

c) a wall with an irregular line of the crest

In the predominant part of the objects the walls of all the described categories were preserved. It results from the primary variety of dimensions, reconstructions carried out in various techniques and a variety of the materials used. The securing solutions which are being carried out should take into account also the geometric form of the preserved walls. There is a photographic documentation below of various types of walls of the objects in ruin. 


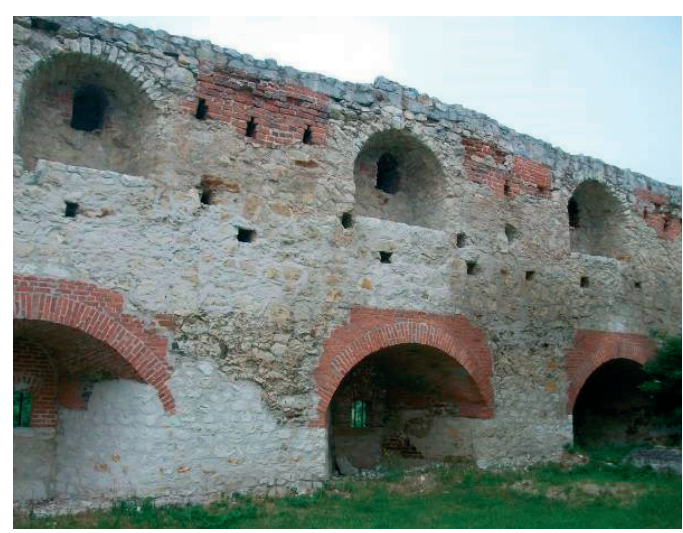

Fig. 4. A massive defensive wall. (The castle of Janowiec on the Vistula River)

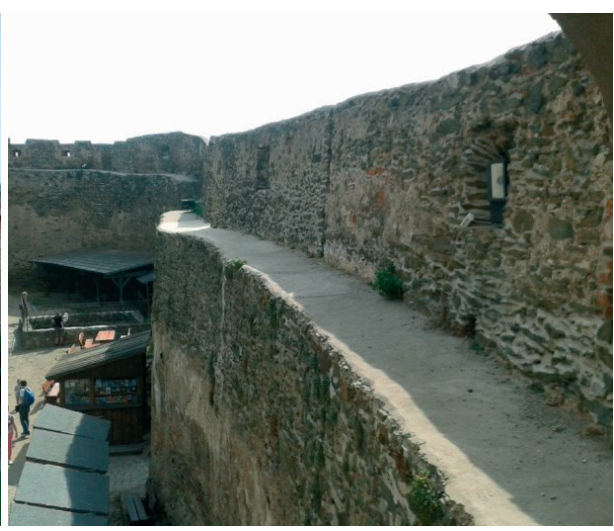

Fig. 5. A massive defensive wall with a high parapet.(The Castle of Bolków)

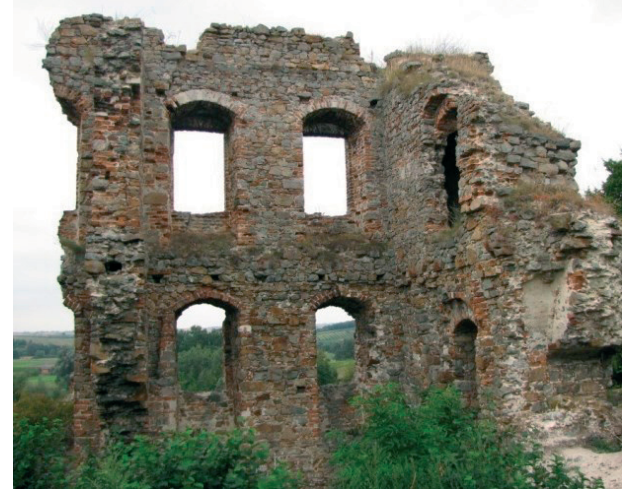

Fig. 6. The wall of the primarily volumetric object. (The castle of Międzygórze)

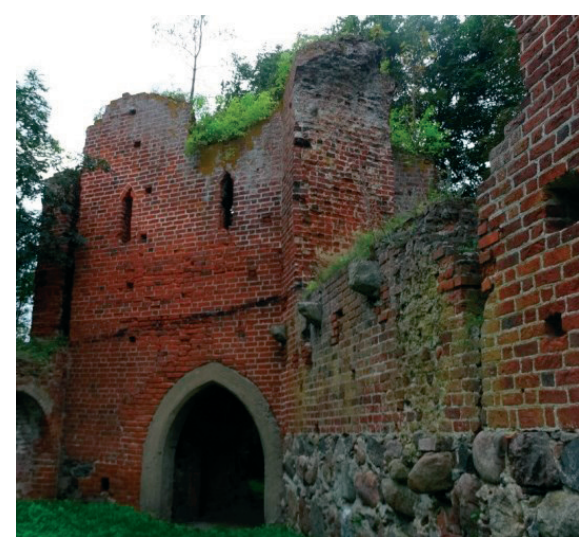

Fig. 8. The Wall of the primarily volumetric object. (The Castle of Pokrzywno)

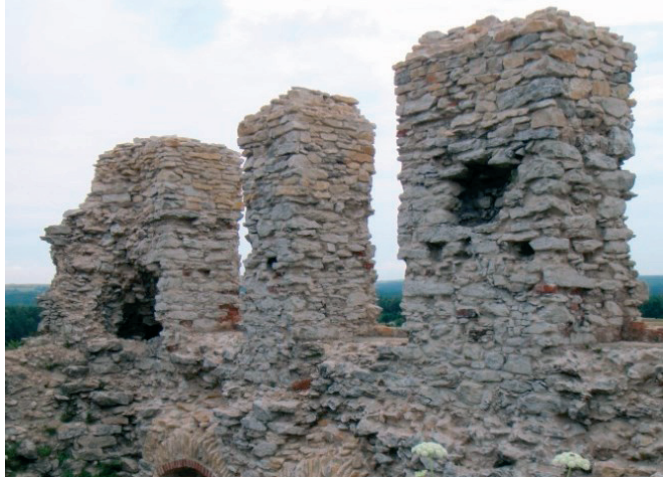

Fig. 7. The wall of the primarily volumetric object. (The castle in Czorsztyn)

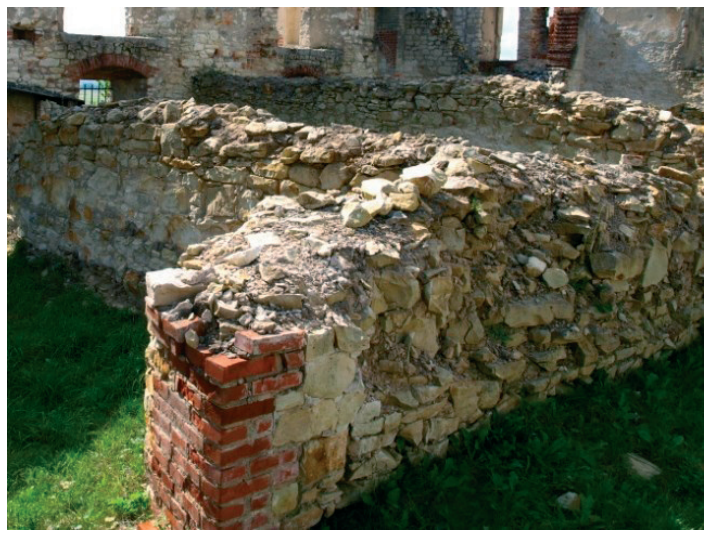

Fig. 9. The Wall of the primarily volumetric object preserved as a relic. (The castle of Janowiec on the Vistula River) 


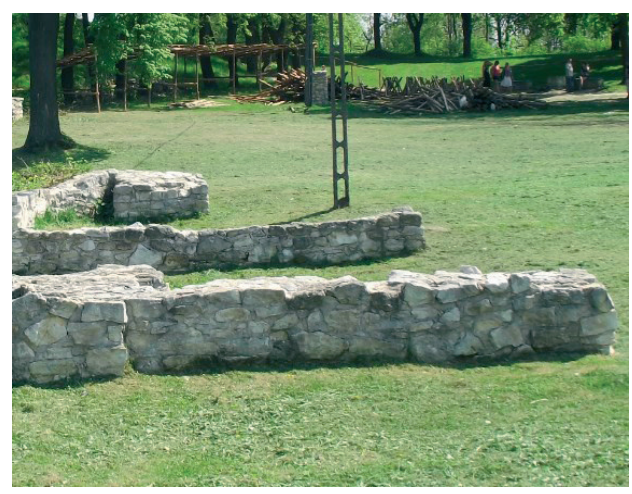

Fig. 10. The Wall preserved as a relic. (The castle in Iłża)

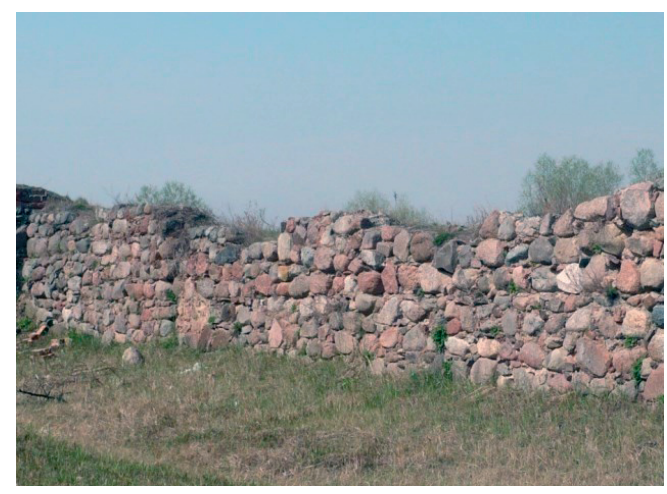

Fig. 11. The relics of the castle intermural space. (The castle in Bobrowniki)

\section{Degradation of the wall crest}

The quality of the construction material has the greatest influence upon the character and dynamics of degradation of the wall crest. These are the physical, chemical and mechanical properties of stone, brick and mortar that affect the durability of the historical crest or the employed security solutions. The very degradation is mostly dependent upon three factors: environmental ones concerned with the climate (humidity, temperature changes, solar radiation, wind), chemical (activity of the chemical compounds inherent for the walls and provided from the outside - aggressive fluids or salts), biotic (activity of microorganisms, fungi, moulds and plants). Explanation of the mechanism of wall degradation is relatively difficult and it requires the knowledge of the progress of particular processes responsible for corrosion and the interdependencies among them.

The predominant part of the degradation processes is strictly related and to a great extent dependent upon excessive humidity. Intensification of the phenomena connected with salt corrosion, frost and biological corrosion results from the increase of the amount of water in the area of the wall crest. Thus it is water that influences most - directly and indirectly - the processes of degradation of brick, stone and mortar. The process is caused, first of all, by the rain water that appears on the surface of the crest when it is raining and then proceeds inside the wall. The rain water soaks through the wall and during the first stage causes dissolution of the binding agents of mortar, damage of the media and then, their complete destruction. As a consequence, the carrying capacity of the parts of the wall devoid of mortar become lower. In case of low walls there is an additional problem of ground-water that may be drawn upwards by the capillary mechanism and the result of the process is a similar degradation as in the case of rainwater.

Humidified materials are destroyed faster also due to the cyclic process of freezing and melting of water contained in the pores of the material and in the wall caverns It increases its volume when freezing which causes the destruction of the material. Degradation caused by the, so-called, frost damages is especially clearly seen at the south elevations of the objects due to the multiple repetitions of the processes of freezing and melting during one season.

Other factors directly related to humidity are the corrosion processes caused by salt. The destructive activity of salt may be multiple. While the solution of salt is constantly transported, its crystallization is accomplished on the surface of the element. Thus, we 
might say that the immediate threat of destruction is less imminent, but the aesthetic impression of the surface of the material is much worse. Various types of salt on the surface of the material may crystallize in the form of blots, damp patches, efflorescences, fluffy deposits and glassy envelopes. The form depends upon the kind and amount of salt and also the conditions of crystallization. In the situation when the velocity of providing the solution is smaller, the temperatures outside are high, the evaporation range moves deeper inside the wall and crystallization is accomplished in the surface layers of the material. It is good to remember that the salts following the process of cristallization in pores and capillars or at the surface of the element are still easily soluble. In case when they are provided with a necessary amount of humidity they pass on to the solution and when the conditions are changed, they crystallize once again. This is especially clearly seen when there is a significant salinity on the outside of the object. The process may be repeated many times, even a dozen or so, dependent upon the atmospheric conditions, causing more and more degradation.

Biological corrosion, also called biodeterioration is understood, in construction, as varied forms of destruction of the elements of a building caused by the activity of living organisms i.e. biological pests. They are mainly green plants, dry rots, mildew fungi, insects, algae, lichens and bacteria. Like in the case of salt the condition of occurrence of most of the above -mentioned organisms is humidity and its increased level is responsible for the intensification of the corrosion processes. The appearance of even a minimal portion of humus in the wall cracks and on top of the crest results in the growth of green plants. At the beginning the dominant plants are mostly small annuals or biennials and grasses. Their growth is particularly intense at the points of greater humidity. Decay processes cause the appearance of humus acids in the wall as well as the increase of the amount of nitrates. Later on, along with the growth of the humus layer (decay of plants, blowing in soil), there are more perennials, bushes and trees. The results of growth of higher plants are similar as in the case of lower plants, additionally there is the danger of the roots growing into the walls. The developing root system (usually growing into the mortar junctions) causes the stratification of the wall leading to a serious degradation.

The above described degradation factors and the degradation processes that imply them practically never appear separately. The state of the crests of the ruined walls is most often caused by all of them or almost all. The photographs below present the degradation of the wall crests pointing out the main degradation factor.

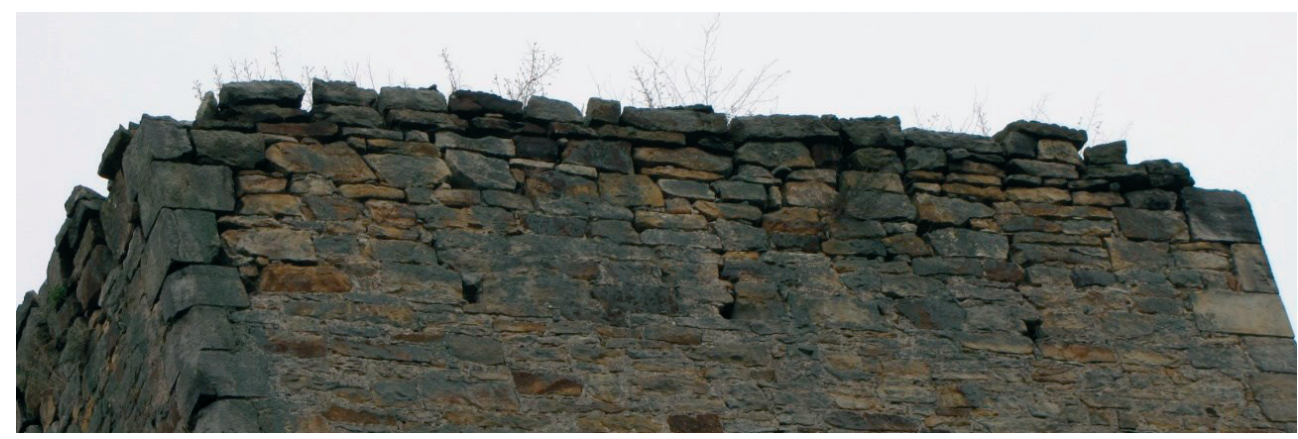

Fig. 12. Degradation of the crest of a stone wall constructed of a really durable material caused by the effect of rainfall and snowfall. 


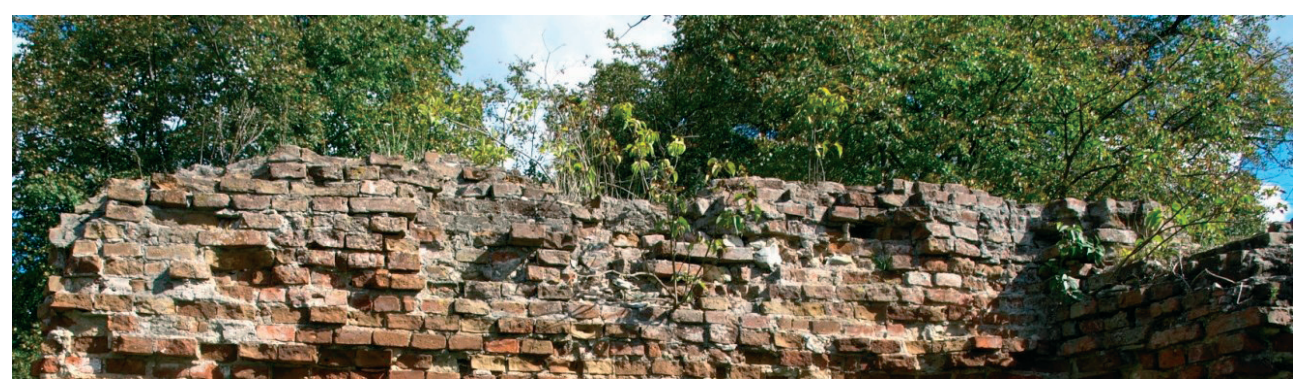

Fig. 13. Degradation of the crest of a ceramic brick wall caused by the effect of rainfall and snowfall

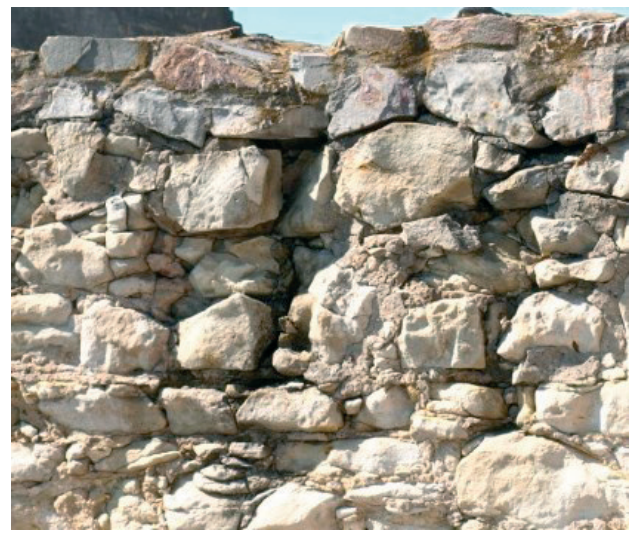

Fig. 14. Degradation of the crest of a stone wall constructed of a low durability material caused by the effect of rainfall and snowfall

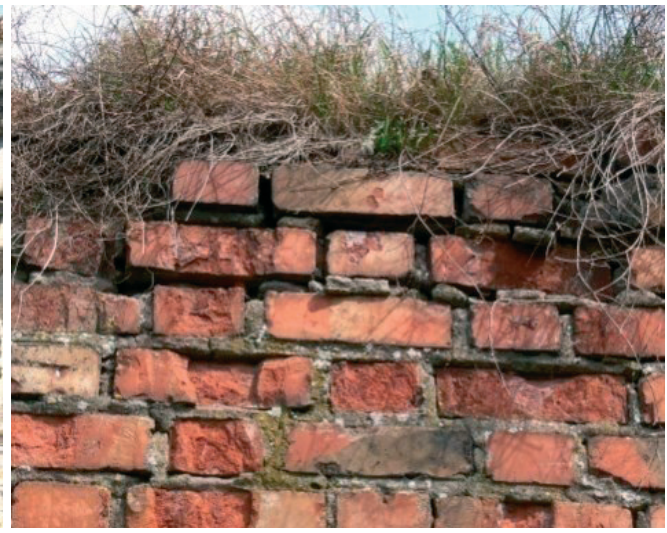

Fig. 15. Degradation of the wall mortar with a good preservation of the wall material.

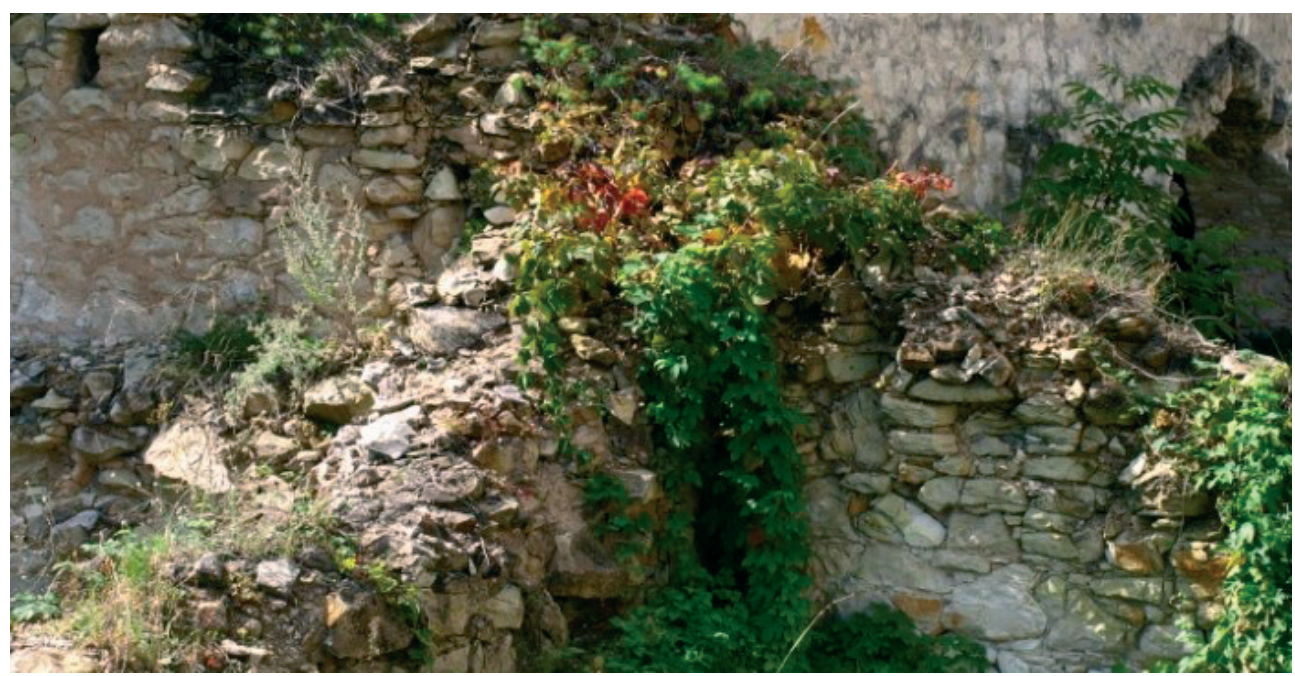

Fig. 16. A significant amount of annuals and perennials causing the degradation of the crown and the loss of legibility of the wall outline (contour). 


\section{Methods of protection of the wall crests}

The works securing the wall crests are usually connected with a partial or complete wall reconstruction. The method of securing the crest is selected with respect to the assumptions of the conservation program. The particular methods of securing the crests are characterized by different durability, legibility and reversibility of their use. The solutions aimed at securing the crest against the degradation factors are dependent from: the type of the wall - the form in which it has been preserved up to modern times, the type of construction and the materials that were used, the state of its preservation, the overall architectural concept for the whole object and the concept of the conservation works. The methods of securing of the wall crests can be divided into two groups.

The first one assumes constructing a new, additional layer on top of the historical wall. According to the assumption it is a layer which may be degraded and in case of degradation it should be cyclically reconstructed. The group includes: reconstruction of a part of the walls, addition to an existing masonry wall, securing the crests with mortars or concrete or a soft capping method.

The second group includes methods which aim at covering or protecting of the historical tissue from the influence of rainfalls or snowfalls. This kind of solutions may be either temporary or durable. The group includes: roofing, securing the crest with sheet metal and chemical coatings.

In all those cases the prior reconstruction of the degraded historical wall is necessary to a smaller or greater extent. The most frequently employed solutions that have been described below aim at securing the wall crests in the objects left as permanent ruin.

- Reconstruction of a part of the walls

Certainly the most efficient solution aimed at the durable securing of the wall crest is the partial reconstruction of the object. Reconstructions may vary in character and they are precisely connected with the concept of architectural works concerning the whole object. Contrary to addition to an existing wall where the height of the new construction of the wall is rather small (several dozen centimeters), in case of reconstruction the new fragment of a wall can even be several meters tall. It is usually the native material that is used in reconstructions, varying only in color, the size of the wall elements or the technology of mortar pointing. In the objects with reconstructed walls one can observe various methods of finishing the new crest. It depends upon the function that is to be performed by the object, or the vision of the design author. It is possible to single out three groups of such reconstructions:

- Walls reconstructed up to their historical height, with the defensive architectural elements, i.e. crenellations, parapets, ramparts, roofing, etc.

- Walls reconstructed lower than their primary height, with a straight finish of the line of the crest, with or without an additional roofing,

- Walls reconstructed lower than their primary height, preserving the kind of plasticity characteristic for the objects defined as permanent ruin. 


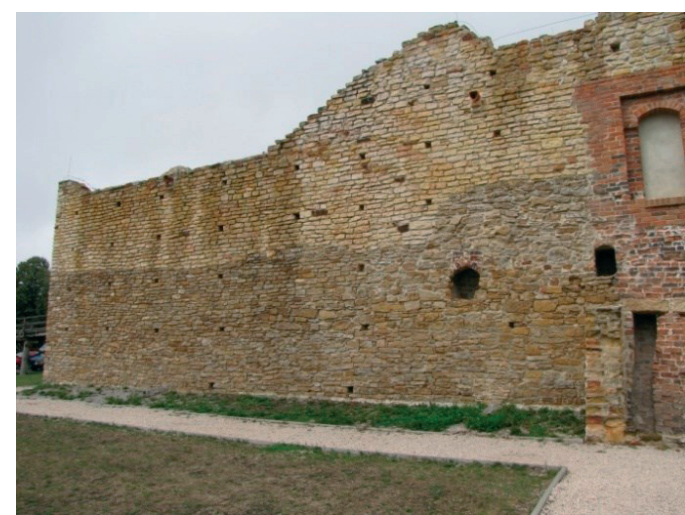

Fig. 17. Reconstruction of substantial fragments of the wall with the material compatible with the historical one. (The castle of Inowłodz)

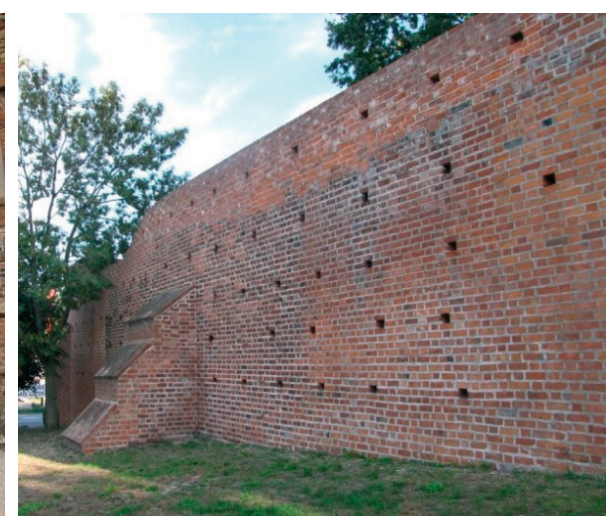

Fig. 18. Reconstruction of substantial fragments of the Wall with the material compatible with the historical one. (The castle of Łęczyca)

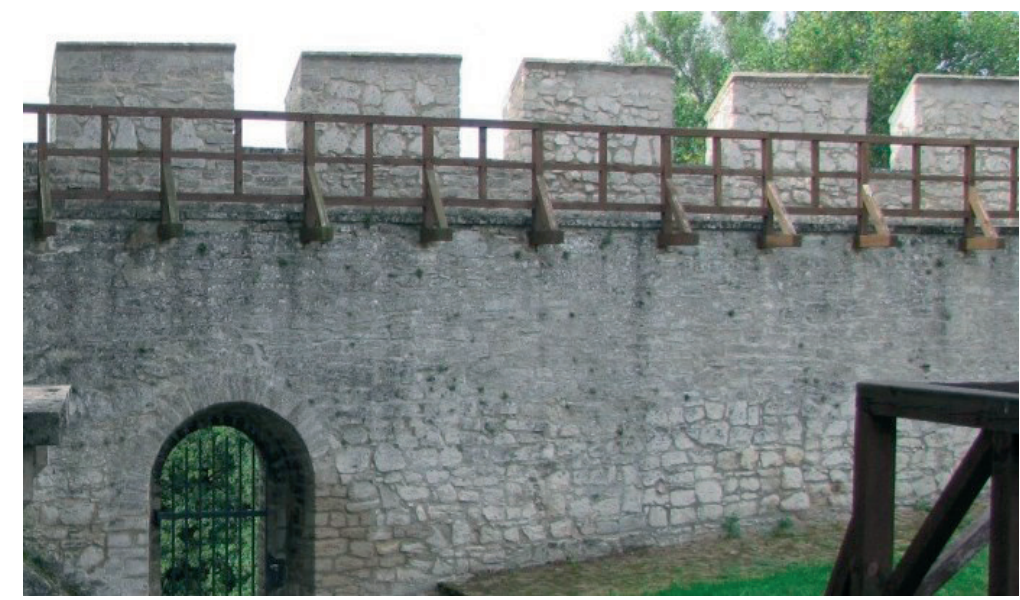

Fig. 19. Reconstruction of substantial fragments of the wall with the material compatible with the historical one)

- Addition to an existing wall

Construction of additional layers of the wall with the use of native or foreign material. It is the basic, simplest and most frequently employed conservation measure aimed at the protection of the monumental substance of the wall crest. It consists in making up for the losses in the upper part of the wall and giving the suitable shape to the wall surface. The very addition to the wall does not stop the process of the crest degradation, but it shifts the degrading activity to the new material, consciously provided for a temporary exchange. An extremely important thing is the proper choice of the wall material and the types of mortar in order to prolong the time of functioning of the construction securing the wall and prevent the situation when the newly introduced materials could be a threat for the historical ones.

Additions are made with the use of native or foreign materials. In case of native material it could become a problem, in the course of years, how to differentiate the additions. In the case when the additions are made of foreign materials, visibly differing from the old ones, the secured crest looks unnatural and one cannot resist the impression that the solu- 
tion is artificial. Undoubtedly an advantage of addition to an existing wall is the possibility of unrestrained shaping of the wall crest which allows to obtain the plasticity compatible with the historical one. Additions are made after the introduction of one more isolation layer, or directly upon the historical material. Certainly a better solution is the use of isolation. It allows supplementary securing of the ancient wall and at the same time as a dividing layer it makes the solution reversible.

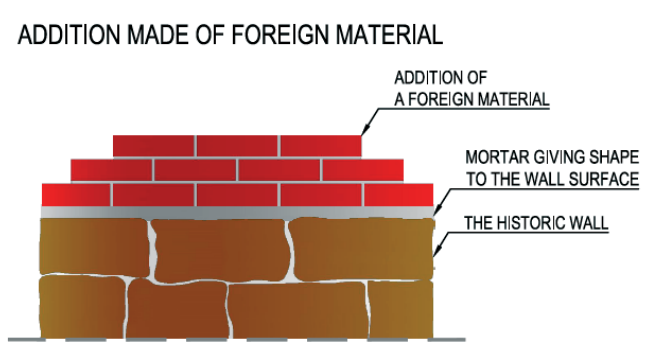

Fig. 20. Addition made of foreign material /A securing layer - addition of a foreign material/ Addition of a foreign material/ Mortar giving shape to the wall surface/ The historic wall

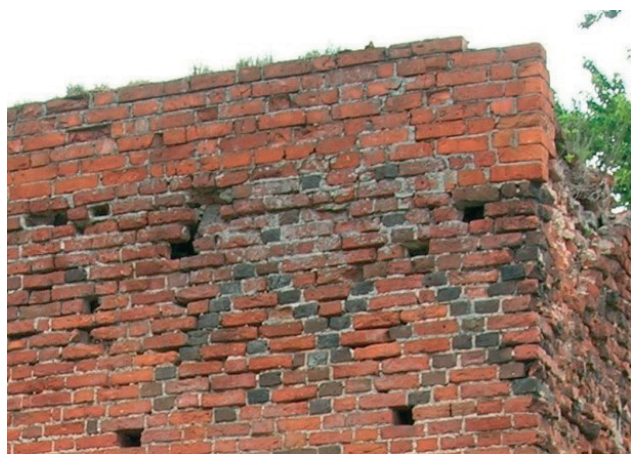

Fig. 22. Addition of the crown made of contemporary brick, on a type of mortar stronger than the original one. (The castle in Bobrowniki)

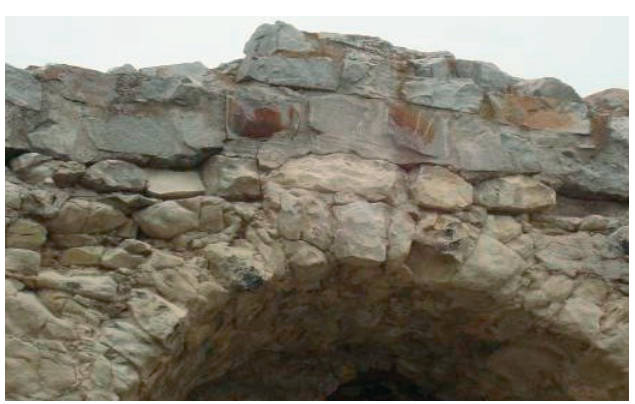

Fig. 21. Addition made of foreign material without the isolation layer. (The castle in Janowiec on the Vistula River)

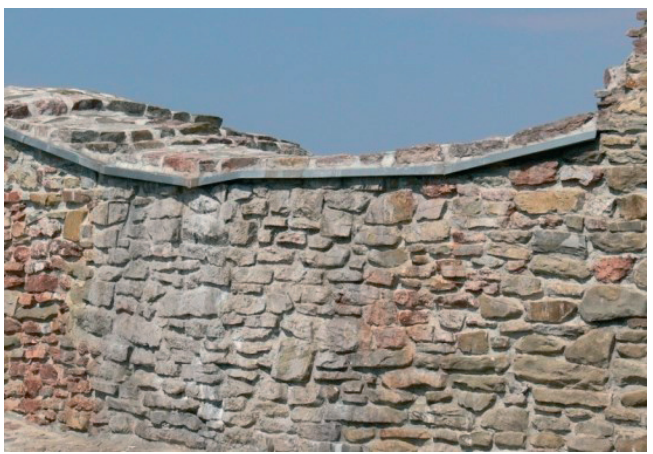

Fig. 23. Addition of the material compatible with the historical one combined with the isolation of sheet metal

- Securing of the crest with mortar or concrete

The method consists in making a tight layer of mortars or concretes upon the degraded wall crown. The kind of securing is made directly upon the historical tissue or the isolation material that is assumed to be a dividing layer which allows a simpler removal of the securing layer without the destruction of the historical wall. Plasticity of the material used for securing of the crest allows the shaping of inclinations leading the rainwater flow out of the object or into it. One of the greatest advantages is the possibility of obtaining the form of the wall crest compatible with the line formed by the natural factors. The mortars which form the securing layer should be as tight as possible, so that rainwater should not permeate the securing layer and in case when there is no isolation, infiltrate into the historic layers. In case of low walls this kind of securing may be perceived as not really aesthetic. 
SECURING LAYER WITH A MOLDED INCLINATION

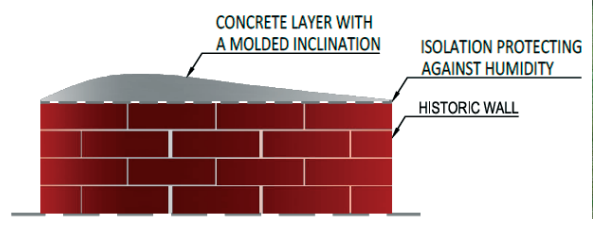

Fig. 24. Crest molding with mortar or concrete./ Securing layer with a molded inclination/ Concrete layer with a molded inclination./ Isolation protecting against humidity/ Historic wall.

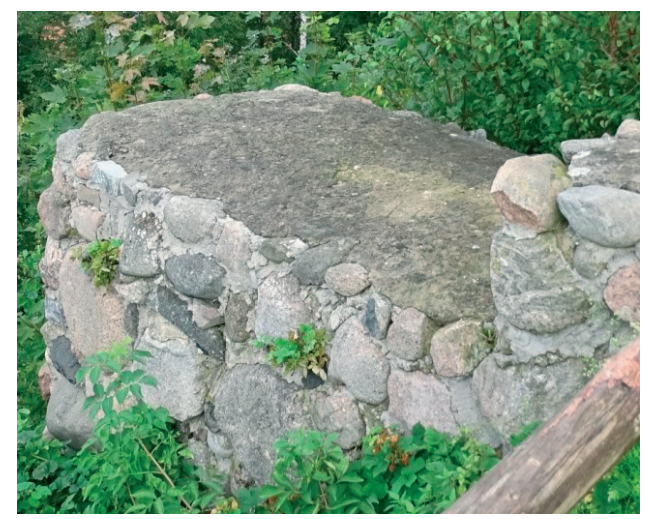

Fig. 26. The crest secured with a layer of cement mortar - with molded inclinations.(The Castle in Kurzętnik)

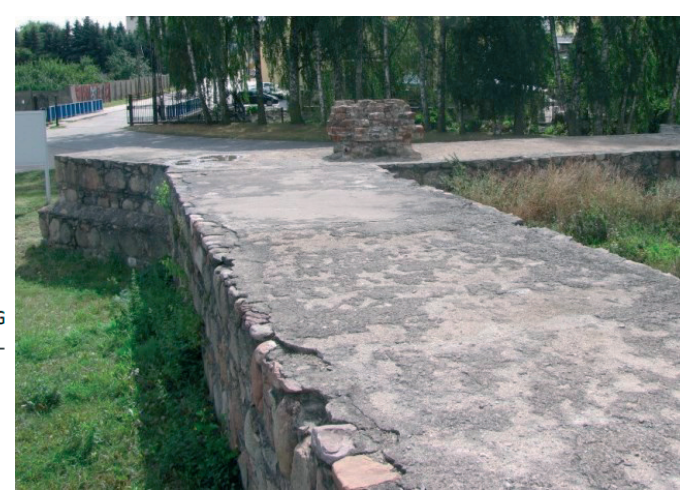

Fig. 25. The crest secured with a layer of cement mortar - without molding. (The castle in Rawa Mazowiecka)

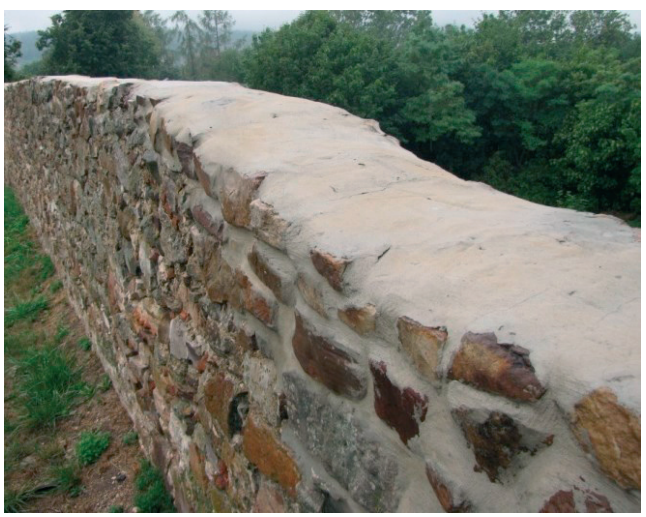

Fig. 27. The crest secured with a mortar layer - with molded inclination.(The castle in Bodzentyn)

- Soft capping

Introduction of a layer of plants upon the wall crest after its previous preparation (with or without isolation, addition to the wall and molding the inclination). The method consists in the intentional covering of the crest with a layer of fertile soil and planting dwarf plants, usually the shallow-rooted grass. This kind of solution is very rarely used because of a whole range of restrictions. The crests secured with soft capping must be supplied with an addition and leveled, which causes the change of the crest plasticity. Vegetation growing on the crest requires some kind of cultivation which makes the access to the crest necessary. Quite a thick layer of humus allowing grass vegetation, creates also a possibility of seeding and growth of undesirable vegetation (perennials, bushes and trees.) 


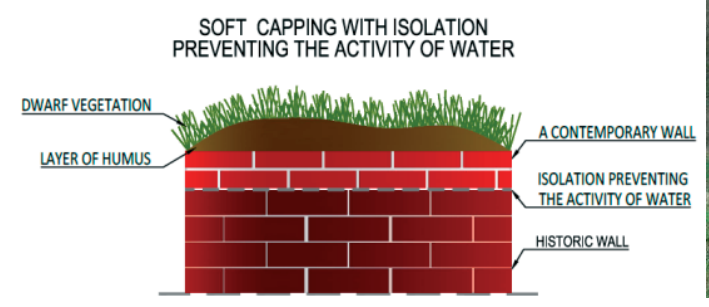

Fig. 28. Soft capping./Soft capping with isolation preventing the activity of water./ Dwarf vegetation/ Layer of humus / A contemporary wall / Isolation preventing the activity of water / Historic wall /

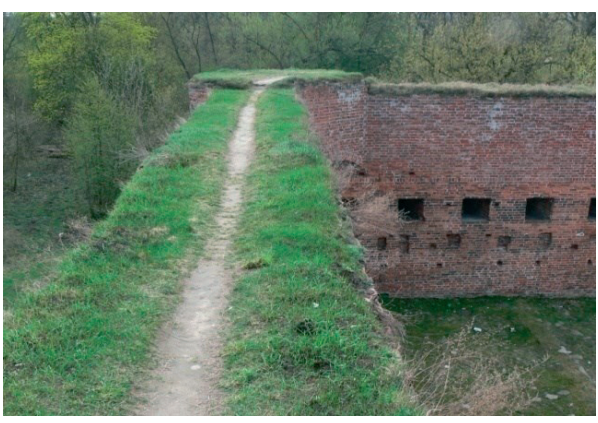

Fig. 29. Soft capping securing the castle wall crest. (The castle of Toruń-Dybów)

\section{- Various types of roofing}

They are not usually a very aesthetic solution, but a durable and reversible securing of the wall crest against the rainfalls. The types of roofing usually made can be divided into two groups. Most frequently the roofing is made as a temporary one, covering the particularly degraded or threatened with degradation portions of walls as well as permanent constructions over the passages allowing to walk upon the crests. In case of temporary solutions one can observe a certain freedom of choice of the materials used and the construction solutions. A permanent roofing, as to the form and material, may be referring to history or completely modern.

- Made of small elements (ceramic or concrete tiles or slates) upon a layer of mortar placed on the crest.

- Made of sheet metal or laminate fixed on the wall crest.

- Made upon the supportive constructions without a permanent fastening of the covering material to the historic tissue.

ROOFING WITH THE USE OF WOODEM OR STEEL CONSTRUCTION

ROOFING WITH STEEL SHEET

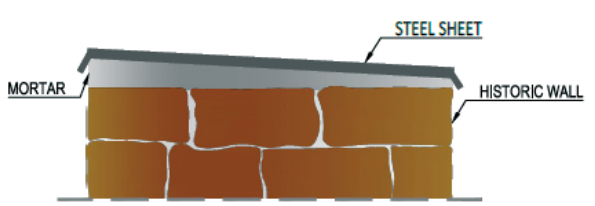

Fig. 30. Roofing of a steel sheet with a layer of molding inclination. / Roofing with steel sheet / Steel sheet / Historic wall/ Mortar/

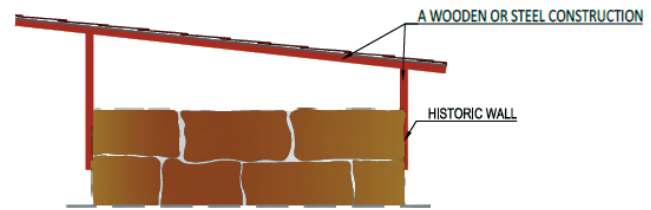

Fig. 31. Roofing with the use of wooden or steel construction. /A wooden or steel construction / Historic wall/ 


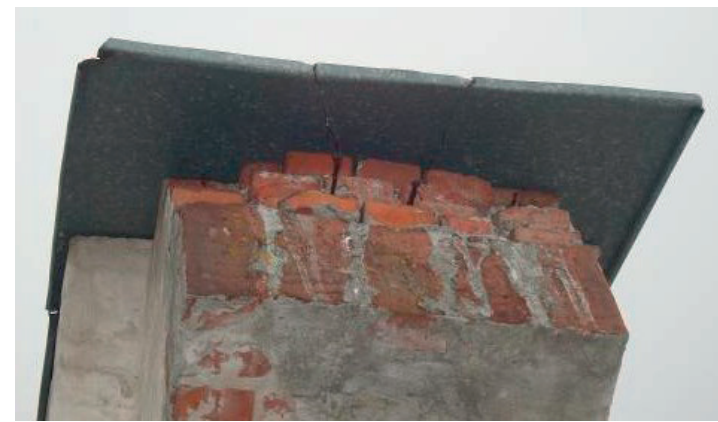

Fig. 32. A steel sheet roofing of the wall crest made directly upon the wall (The castle in Janowiec on the Vistula River)

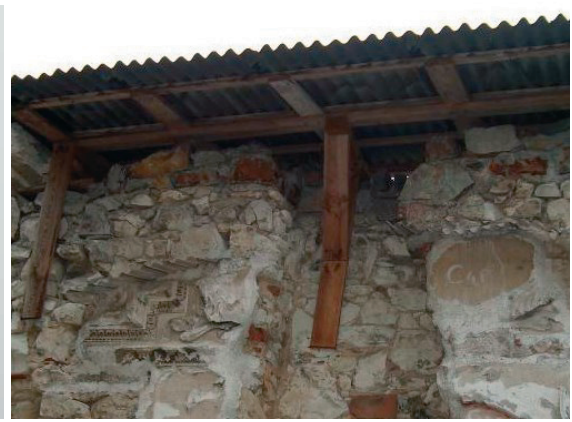

Fig. 33. Securing of the crest and a detail by a wooden construction with corrugated sheet metal (The castle in Janowiec on the Vistula River)

- Securing the crest with sheet metal

The securing consists in making the cover of soft sheet metal directly upon the top layer of the wall crest without any later addition to the existing wall. At the first stage the crest needs a suitable preparation of the surface, all the holes and caverns must be filled. The surface elements of the crest should be cylindrical in shape. The crest should not be leveled, as it would make the sheet metal fixing more difficult. A metal sheet is put on the prepared crest and then it is hammered so that it could acquire the shape retaining the pattern of the crest. Pulling the metal sheet over the front and hammering it down allows a better connection between the metal and the wall. The method is highly efficient and durable.

\section{SECURING MADE OF LEAD SHEET METAL} FORMED UPON THE CREST

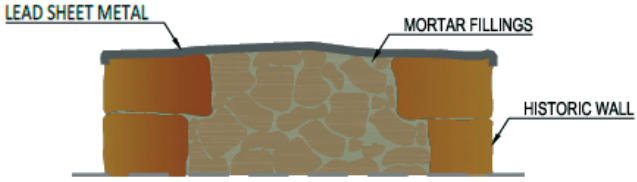

Fig. 34. Making a sweet metal cover on the Wall crest./ Securing made of lead sheet metal formed upon the crest./ Lead sheet metal/ Mortar fillings / Historic wall/

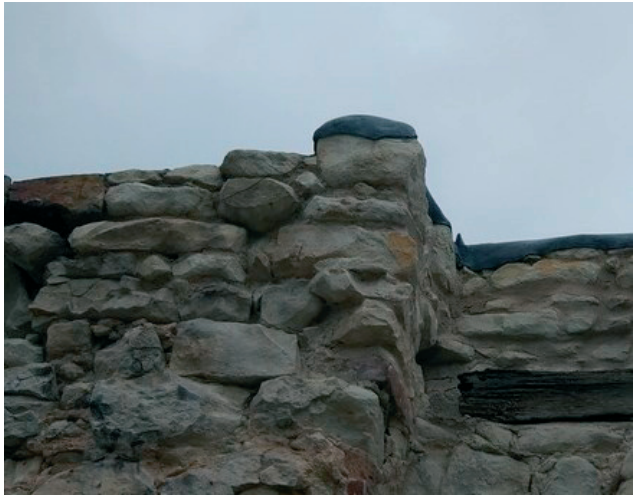

Fig. 35. The crest fragment secured with lead sheet metal. (The castle in Janowiec on the Vistula River)

- Chemical methods

The securing devices of this type can make use of hydrophobic or sealing preparations. Along with the dynamic development of construction chemistry at the end of $20^{\text {th }}$ century chemical substances started to be used for surface hydrophobia of stone and brick wall crests. Their proper application requires the fulfillment of a whole range of conditions 
concerning the type of a preparation, the type and quality of the base (the wall material, mortar), humidity of the secured surfaces, a suitable preparation of the wall crest surface etc.

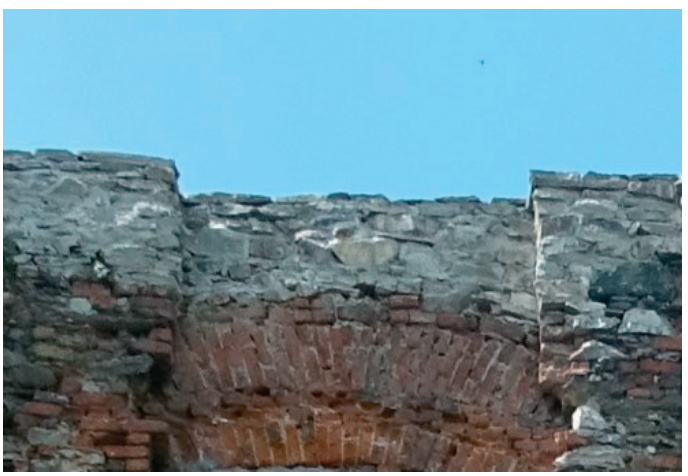

Fig. 36. Securing of the added crest with a cover (The castle in Ząbkowice Śląskie)

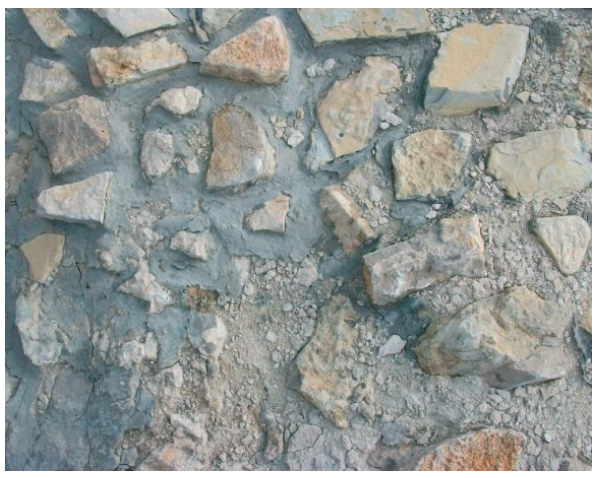

Fig. 37. The degraded chemical cover of the crest.(The castle in Rabsztyn)

Analyzing the objects in which the wall crests were secured with the use of various types of technologies and materials one can state that the greatest influence upon the solution durability is exerted by introducing the isolation layer between the historic tissue and the material above. Introduction of the diaphragm does not influence the new securing layer - it remains exposed to degrading processes and slowly deteriorates. Isolation prevents, however, permeation of water into the lower layers, significantly restricting degradation of historic tissue. When securing the crest, both coating isolation and layer isolation may be used and their construction does not differ from the material used in contemporary buildings. In order to make a securing one can use roofing paper, sheet steel, sheet lead, laminates, bitumic isolation coatings and plastics. An additional advantage of introducing isolation is reversible. In case when it is necessary to recreate the primary state, it will not be necessary to interfere significantly in the historic layers.

The table below provides a specification of basic advantages and disadvantages of the securing solutions used in the objects left as permanent ruin.

Table 1. Basic advantages/disadvantages of the securing solutions used in the objects left as permanent ruin

\begin{tabular}{lll}
\hline $\begin{array}{l}\text { Type } \\
\text { of securing }\end{array}$ & Advantages & Disadvantages \\
\hline $\begin{array}{l}\text { Reconstruction } \\
\text { of a part of the } \\
\text { wall }\end{array}$ & $\begin{array}{l}\text { Durability of the securing of the historic } \\
\text { wall } \\
\text { Possibility of providing solutions allowing } \\
\text { the flow of rainwater from the crest }\end{array}$ & $\begin{array}{l}\text { Irreversibility } \\
\text { Indiscernibility while using the material of a } \\
\text { similar color and dimensions } \\
\text { The risk of introducing cubatures incompat- } \\
\text { ible with the conservator's regulations } \\
\text { Presenting the natural processes of the } \\
\text { origin of ruins in a false way }\end{array}$ \\
\hline $\begin{array}{l}\text { Addition of } \\
\text { native material }\end{array}$ & $\begin{array}{l}\text { Irreversibility of the introduced solutions } \\
\text { Possibility of shaping the line of the crest } \\
\text { according to the one obtained by natural } \\
\text { factors }\end{array}$ & $\begin{array}{l}\text { Indiscernibility after some time } \\
\text { In case of lack of isolation - irreversibility } \\
\text { of the solution } \\
\text { Indiscernibility while using the material of a } \\
\text { similar colour and dimension }\end{array}$ \\
\hline
\end{tabular}




\begin{tabular}{|c|c|c|}
\hline $\begin{array}{l}\text { Type } \\
\text { of securing }\end{array}$ & Advantages & Disadvantages \\
\hline $\begin{array}{l}\text { Addition of a } \\
\text { foreign material }\end{array}$ & $\begin{array}{l}\text { Discernibility of the introduced solutions } \\
\text { Possibility of shaping the crest line accord- } \\
\text { ing to the one obtained by natural factors }\end{array}$ & $\begin{array}{l}\text { In case of lack of isolation - irreversibility } \\
\text { of the solution }\end{array}$ \\
\hline $\begin{array}{l}\text { Making the crest } \\
\text { profile of mortar } \\
\text { or concrete }\end{array}$ & $\begin{array}{l}\text { Opportunity to allow the flow of rainwater } \\
\text { from the crest } \\
\text { Obtaining the plasticity of the wall line } \\
\text { compatible with the one formed in a natural } \\
\text { way }\end{array}$ & $\begin{array}{l}\text { Using cement as a component of the } \\
\text { material has a negative effect upon the } \\
\text { historic material }\end{array}$ \\
\hline Soft capping & & $\begin{array}{l}\text { Necessity of making substantial additions in } \\
\text { order to level the crest } \\
\text { The risk of appearing of species exerting } \\
\text { destructive, undesirable effect upon the } \\
\text { historic wall }\end{array}$ \\
\hline Roofing & $\begin{array}{l}\text { Securing both the crest and the front } \\
\text { immediately under the crest } \\
\text { Reversibility of the solution }\end{array}$ & $\begin{array}{l}\text { Low aesthetic impression of most solutions } \\
\text { Change of the wall crest natural plasticity }\end{array}$ \\
\hline $\begin{array}{l}\text { Securing the } \\
\text { crest with sheet } \\
\text { metal }\end{array}$ & $\begin{array}{l}\text { High durability of the solution } \\
\text { Reversibility of the solution }\end{array}$ & $\begin{array}{l}\text { Low aesthetic impression } \\
\text { Necessity to determine the sweet metal } \\
\text { effect upon the preservation of the wall } \\
\text { material }\end{array}$ \\
\hline $\begin{array}{l}\text { Chemical } \\
\text { methods }\end{array}$ & $\begin{array}{l}\text { Obtaining the wall line plasticity compatible } \\
\text { with the one formed in a natural way }\end{array}$ & $\begin{array}{l}\text { Low durability of the solution } \\
\text { Part of the substance may have a negative } \\
\text { effect upon the historic material }\end{array}$ \\
\hline $\begin{array}{l}\text { Introduction of } \\
\text { the additional } \\
\text { isolation layers }\end{array}$ & $\begin{array}{l}\text { Increasing the durability of all solutions } \\
\text { Ensuring the reversibility of the works upon } \\
\text { securing the crest, isolation has a role of a } \\
\text { dividing layer }\end{array}$ & $\begin{array}{l}\text { Lower aesthetic impression in case of } \\
\text { isolation protruding from the front or using } \\
\text { profiles removing water }\end{array}$ \\
\hline
\end{tabular}

\section{Summary}

Due to the great variety of the wall crests in state of a permanent ruin concerning their construction, material, state of preservation, height and thickness as well as the shape of the crest line it is impossible to point out one universal method of wall securing. In many cases there is a necessity of introducing various solutions within the range of one object and sometimes even one fragment of an object.

For the durability of the solution it is the key issue to introduce the isolation layer between the historic tissue and the modern supplement. The layer also ensures the reversibility of the solutions employed and in case when there is a necessity of recreation of the previous state, there will not be any serious interference with the historic layers.

The problem of a suitable way of removing water from the wall crest and its further distribution has not yet been finally resolved. It specially refers to the walls of highly irregular wall crest.

The above described ways of securing result from a compromise between the necessity of protecting the wall crests and the suitable way of their exposition that would not falsify history.

All the securing solutions require the permanent control of their state. Visual assessment supplemented with photographic and film documentation should be carried out twice a year at least, i.e. before the winter season and immediately after its end. 


\section{References}

1. Ashurst J. Conservation of Ruins, Oxford 2007.

2. Głuszek C. Współczesne uzupetnienia historycznych ruin zamkowych - charakterystyka problemu, [w:] Zamki w ruinie - Zasady postepowania konserwatorskiego, Warszawa-Lublin 2012.

3. Hanssen, S.V., Viles, H.A. Can plants keep ruins dry? A quantitative assessment of the effect of soft capping on rainwater flows over ruined walls, Ecological Engineering 71 (2014).

4. Jasieńko J., Mierzejewska O, Hamrol K., Misztal W. Fixing the Wall crests in historic building structures to be exhibited as permanent ruin, Conservation News 30/2011

5. Lee Z., Viles H.A., Wood C.H. Soft capping historic walls: A better way of conserving ruins?, English Heritage Research Project Report, 2009

6. Łukaszewicz J. W. Współczesne materiały budowlane w konserwacji ruin, [w:] Zamki w ruinie - Zasady postepowania konserwatorskiego, Warszawa-Lublin 2012.

7. Przyłęcki M. Techniczno-biologiczna metoda zabezpieczania i ekspozycji murów trwałych ruin, Ochrona Zabytków 34(1-2) (1981)

8. Stępień P. M. Dwa zamki pienińskie - Czorsztyn i Pieniny. Projekty, prace i kilka refleksji, [w:] Zamki w ruinie - Zasady postepowania konserwatorskiego, Warszawa-Lublin 2012.

9. Szmygin B. Historyczne ruiny średniowiecznych zamków w Polsce - Ocena stanu zasobu i prac konserwatorskich, [w:] Zamki w ruinie - Zasady postępowania konserwatorskiego, Warszawa-Lublin 2012.

10. Tajchman J. Metoda zabezpieczania i rewitalizacji ruin historycznych jako szczególny rodzaj konserwacji i restauracji zabytków architektury, Materiały z międzynarodowej konferencji naukowej, Gubin 2008.

11. Tajchman J. Na czym polega metoda ochrony, konserwacji i zagospodarowania ruin zamkowych, [w:] Zamki w ruinie - Zasady postepowania konserwatorskiego, Warszawa-Lublin 2012.

12. Trochonowicz M. Korozja biologiczna w obiektach budowlanych, [w:] Wybrane zagadnienia ochrony i konserwacji zabytków architektury, Wydawnictwo Politechniki Lubelskiej Lublin 2007. 